\title{
The Moroccan Anti-Atlas: the West African craton passive margin with limited Pan-African activity. Implications for the northern limit of the craton
}

\author{
Nasser Ennih ${ }^{\mathrm{a}}$, Jean-Paul Liégeois ${ }^{\mathrm{b}}$ \\ a Department of Geology, Faculty of Sciences, BP 20, 24000 El Jadida, Morocco \\ b Departement de Géologie, Section de Géologie, Musée Royal de l'Afrique Centrale, Leuvensesteenweg 13, \\ B-3080 Tervuren, Belgium
}

Received 6 October 2000; accepted 18 April 2001

\begin{abstract}
The Moroccan Anti-Atlas region, located south of the South Atlas Fault, has been viewed traditionally as containing two segments separated by the Anti-Atlas Major Fault. These two segments are said to consist of: (a) 600-700 Ma Pan-African segment located in the northeast; and (b) $\sim 2$ Ga Eburnian segment situated to the southwest. On the basis of observations in the Zenaga and Saghro inliers and of a recent literature review, we suggest that this subdivision is inappropriate in that Eburnian and Pan-African materials occur throughout the Anti-Atlas region: the entire Anti-Atlas is underlain by Eburnian crust, unconformably overlain by a lower Neoproterozoic passive margin; allochthonous Pan-African ocean crustal slices were thrust onto the West African craton (WAC) passive margin sequence $\sim 685 \mathrm{Ma}$ ago as a result of Pan-African accretion tectonics; high-level high-K calc-alkaline and alkaline granitoids locally intruded the Anti-Atlas sequence as a whole at the end of the Pan-African orogeny at 585-560 Ma; the intervening 100 m.y. interval was marked by quiescence. This succession of events can be related to the behaviour of one single rigid cratonic passive margin during an orogeny and correlated to the Pan-African events that occurred to the east in the Tuareg shield and to the north in Avalonian terranes. This model implies that the actual northern limit of the WAC is located at the South Atlas Fault (SAF) and not at the Anti-Atlas Major Fault (AAMF). We propose that the AAMF corresponds to the southwestern boundary of an aulacogen that formed along the northern margin of the WAC during early Neoproterozoic times. This is consistent with the development of the Gourma aulacogen on the eastern side of the WAC. This model further suggests that the northeastern boundary of the WAC occurs north, and not south, of Ougarta (Algeria). Support for this model is provided by geological and geophysical evidence. (C) 2001 Elsevier Science B.V. All rights reserved.
\end{abstract}

Keywords: Anti-Atlas; Morocco; West African craton; Tuareg shield; Eburnian; Pan-African

* Corresponding author. Tel.: + 32-2-6502252; fax: + 32-2-6502252.

E-mail addresses: ennih@ucd.ac.ma (N. Ennih),jplieg@ulb.ac.be (J.-P. Liégeois). 


\section{Introduction}

The Moroccan Anti-Atlas marks the northern boundary of the Eburnian (c. 2 Ga) West African craton (WAC). The Anti-Atlas region has been impacted by the Pan-African, Hercynian and Alpine orogenies, with the latter two orogenies affecting primarily the Meseta-Atlas domain north of the South Atlas Fault (SAF) and minimally the Anti-Atlas domain, located south of the SAF (Fig. 1). The Anti-Atlas is composed of a Precambrian crystalline basement unconformably overlain by slightly folded Phanerozoic sedimentary rocks. The Precambrian basement crops out in a series of inliers (Fig. 1). Most workers have subdivided this region into two parts separated by the Anti-Atlas Major Fault (AAMF), delineated by the Bou Azzer Pan-African ophiolite (Leblanc, 1981): Eburnian (c. $2 \mathrm{Ga}$ ) basement rocks occur southwest of the AAMF; Pan-African (700-600 Ma) rocks occur northeastern of the fault (Fig. 1). However, this simple subdivision is complicated by Pan-African granites that crop out southeastern of the AAMF (Ait Malek et al., 1998) and by lithologies only slightly affected by the Pan-African orogeny that occur northeast of the AAMF (Choubert, 1963; Fekkak et al., 1999).

We propose a model integrating these apparent discrepancies and suggest that the Eburnian basement underlies the entire Anti-Atlas region, northeast and southwest of the AAMF. The PanAfrican orogeny generated only discrete thrust units and late granite associated with major shear zones. Among the Anti-Atlas Pan-African rocks, occur remnants of an oceanic convergent margin whose vergence continues to be debated. Recently, Hefferan et al. (2000) supported the idea of a northward-dipping subduction zone, inclined away from the WAC, mainly on the basis of a regional comparison with Pan-African belts surrounding the craton. The model we propose addresses the Anti-Atlas subduction vergence and raises important issues as to the existence of 'polycyclic' Anti-Atlas terranes and origin of both the Anti-Atlas Major Fault and SAF.

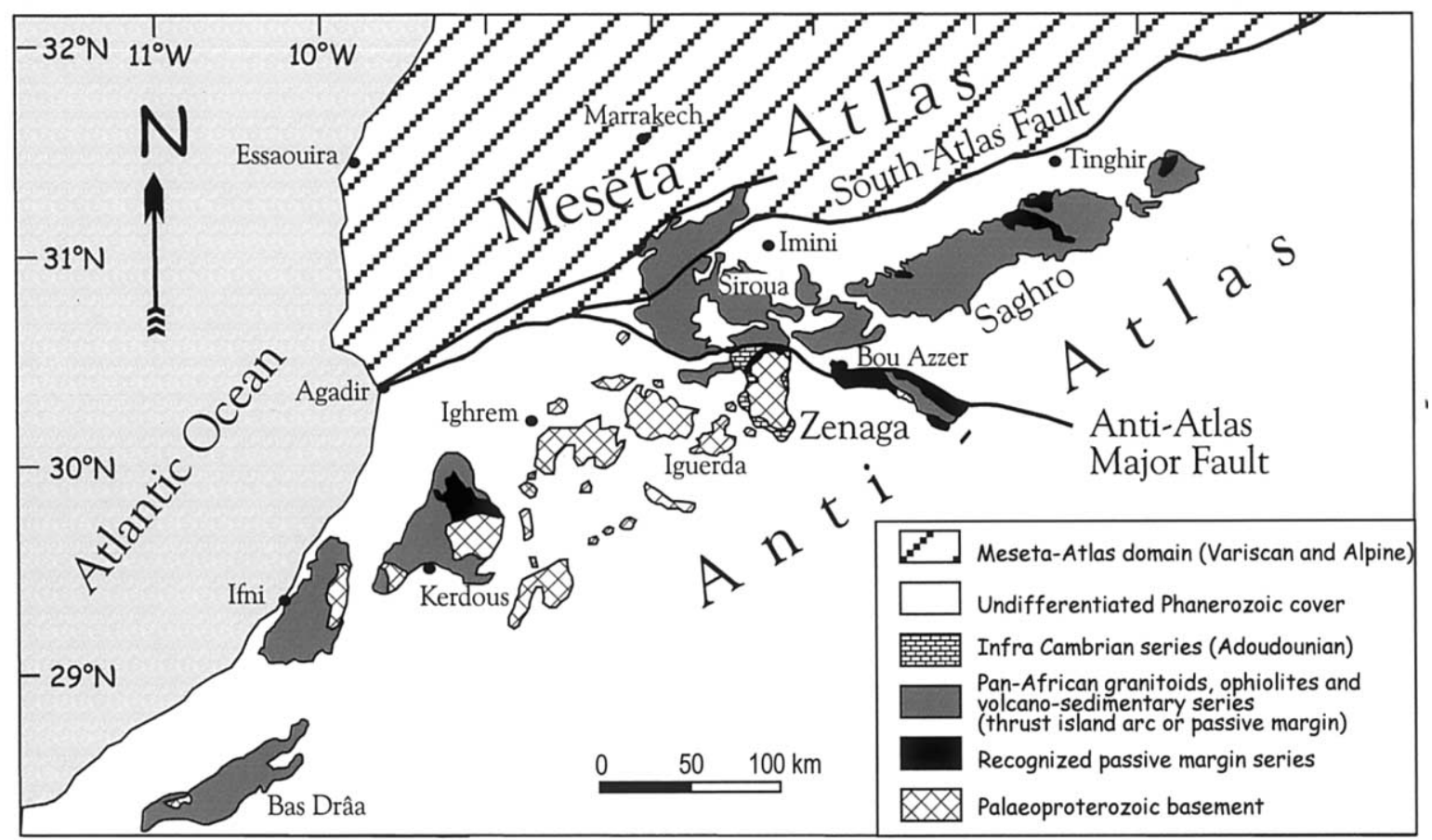

Fig. 1. General sketch map of the Anti-Atlas, with its Precambrian inliers, and Atlas regions. 


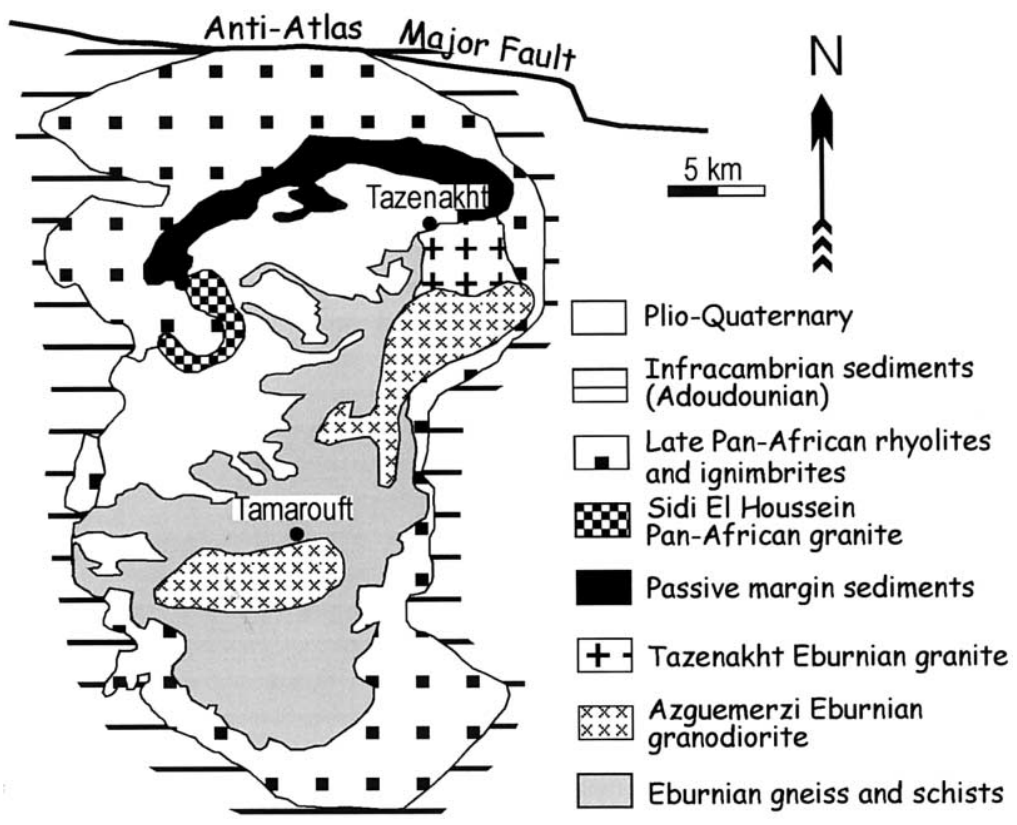

Fig. 2. Geological map of the Zenaga inlier.

\section{The Anti-Atlas Precambrian inliers}

A crystalline basement is exposed in a series of NE trending inliers throughout the Anti-Atlas region. Recent studies raise questions as to the relative importance of Eburnian and Pan-African intrusions south of the AAMF. Structural observations in the Kerdous inliers led Nachit et al. (1996) to attribute deformations solely to the PanAfrican orogeny. Nachit et al. (1996) questioned the Eburnian age attributed to the Tahala granite by Charlot (1978), using a $\mathrm{Rb}-\mathrm{Sr}$ whole rock isochron. They suggested that the Eburnian age represented a contamination due to magma mixing from lower crustal Eburnian granodiorite basement. A recent geochronological study (U$\mathrm{Pb}$ on zircon; Aï Malek et al., 1998) has shown the presence of granitoids of both Eburnian $(1987 \pm 20 \mathrm{Ma}$ in Bas Drâa and $2050 \pm 6 \mathrm{Ma}$ in Igherm inliers; Fig. 1) and Pan-African (575.3 \pm 1.7 Ma in Bas Drâa, $583 \pm 11$ and $560.4 \pm 1.7 \mathrm{Ma}$ in Kerdous inliers) age. Although Aït Malek et al. (1998) did not report U-Pb Eburnian ages in the Kerdous inlier, they concluded that all inliers south of the Anti-Atlas Major Fault are polycyclic as proposed by Charlot (1978).
North of the AAMF, the Saghro inlier (Fig. 1) has been interpreted as a Pan-African oceanic island arc and associated environments (Saquaque et al., 1989). However, several observations do not corroborate this proposal: based on petrographical studies, muscovite-bearing granitoids in Imiter (Eastern Saghro; Choubert, 1963; Hindermeyer, 1977) have been attributed to the Eburnian orogeny; late alkaline rhyolite, granite, and rift sequence are present and finally a lower Neoproterozoic detrital series with a proximal continental source interstratified with continental tholeiitic basalts is located below the postulated island arc series (Fekkak et al., 1999).

\section{Zenaga inlier: an Eburnian edifice with local and high-level Pan-African effects}

The Zenaga inlier, which is bordered to the north by the AAMF (Fig. 1), contains two large Palaeoproterozoic granitoid plutons (Fig. 2): the Azguemerzi pluton and Tazenakht pluton yielded a whole rock $\mathrm{Rb}-\mathrm{Sr}$ age of $1865 \pm 29$ and $1735 \pm$ $11 \mathrm{Ma}$, respectively (Charlot, 1978). Although 
these ages correspond most probably to late isotopic resettings, the emplacement age of these plutons cannot be much older since their $\mathrm{Sr}$ initial isotopic ratios are quite low $\left({ }^{87} \mathrm{Sr} /{ }^{86} \mathrm{Sr}_{\mathrm{i}}=0.705\right.$ and 0.708 ) for acidic rocks with relatively high $\mathrm{Rb} / \mathrm{Sr}$ ratios. As in the case of the Bas Drâa and Igherm inliers (Aït Malek et al., 1998) an age around $2 \mathrm{Ga}$ is more likely. The Azguemerzi granodiorite-monzogranite is peraluminous, bearing muscovite, garnet, sillimanite and very scarce cordierite. It contains rare metasedimentary xenoliths and no MME (mafic microgranular enclaves). It shows a strong magmatic foliation locally evolving to a gneissic structure in shear zones. The Tazenakht porphyritic two-mica granite (monzo- to syenogranite) is often mylonitic and retrogressed under greenschist facies conditions. The country-rocks of these plutons are amphibolite facies metamorphic rocks (Fig. 2), mainly micaschists and paragneisses locally migmatized.

Eburnian and Pan-African deformations may be characterized through structural, petrological and magnetic susceptibility anisotropy studies (Ennih et al., 2001): in Zenaga, the Eburnian orogeny is formed of three deformation phases, the main one being oriented NE-SW. This deformation affects the whole Palaeoproterozoic basement under amphibolite facies conditions with the development of a sillimanite-K-feldspar-muscovite-quartz paragenesis, corresponding to a temperature of about $640{ }^{\circ} \mathrm{C}$ and a pressure around $0.5 \mathrm{GPa}$. The peraluminous garnet-muscovite-bearing Azguemerzi granitoid has been folded into a dome shape which is overturned to the NW with a major plastic deformation corresponding to a magmatic flow induced by a regional stress field. The Eburnian Tazenakht granite is not affected by this deformation.

In contrast, the Pan-African deformation shows a strong $\mathrm{N}-\mathrm{S}$ gradient intensity increasing towards the AAMF. Located in the north of the Zenaga inlier, the Tazenakht granite (Fig. 2) has been strongly affected by this deformation. This early Pan-African tectonics is represented by a mylonitization phase with a reduction of crystal sizes, in particular that of the K-feldspar megacrysts that are transformed to phyllitic min- erals. This mylonitization accompanied a sinistral ductile strike-slip deformation that led to greenschist facies metamorphism (Ennih et al., 2001). It corresponds to the major B1 phase of Leblanc (1981), characterized by isoclinal folds and greenschist facies schistosity developed under a $\mathrm{N}-\mathrm{S}$ directed stress.

Pan-African magmatism is late, alkaline in composition and located to the NW of the inlier (Fig. 2). This magmatism is represented by the Sidi El Houssein pink metaluminous granite and the associated alkaline to peralkaline ignimbritic volcanism (rhyolite and rhyodacite). This magmatism marked the end of the Pan-African orogeny.

Between the Eburnian and Pan-African events, detrital turbiditic sediments were deposited upon the Eburnian basement in a passive margin environment. They are well-preserved and display abundant sedimentary structures (ripple marks, mud cracks, load casts...) demonstrating the discrete nature of the Pan-African deformation in Zenaga.

\section{The other Anti-Atlas inliers, south of the Anti-Atlas Major Fault}

The other inliers south of the AAMF (Fig. 1) are also composed of an amphibolite facies (sillimanite + K-feldspar) Palaeoproterozoic basement cut by peraluminous (garnet \pm sillimanite) porphyritic (oriented megacrysts) granites and by muscovite-bearing leucogranites that include large xenoliths of paragneisses and micaschists. Mafic microgranular enclaves (MME) are absent. These granitoids, about 2 Ga old (Aït Malek et al., 1998), are affected by a heterogeneous transpressive deformation inducing a major greenschist facies mylonitization. This deformation corresponds to $\mathrm{E}-\mathrm{W}$ oriented ductile strike-slip zones similar to the deformation associated with the AAMF in the Zenaga inlier. Post-Eburnian, probably Neoproterozoic, turbiditic sedimentary sequences are affected by this mylonitization (Kerdous inlier; Nachit et al., 1996) and can be correlated with those of the Zenaga inlier.

The Pan-African granitoids in these inliers are late (585-560 Ma) and form two groups (Ait 
Malek et al., 1998): (1) K-rich granodiorites and monzogranites rich in $\mathrm{Ba}, \mathrm{Sr}$ and $\mathrm{REE}$, very rich in MME; (2) younger alkaline to peralkaline pink granites associated with rhyolitic and ignimbritic volcanism (Kerdous and Bas Drâa inliers), comparable to the Sidi El Houssein magmatism in the Zenaga inlier. These two magmatic types are clearly different from the MME-free peraluminous Eburnian granitoids.

\section{The Saghro inlier, north of the Anti-Atlas Major Fault}

The Saghro inlier comprises a Pan-African ophiolite suite as in Bou Azzer (obducted at 686 Ma; Leblanc, 1981) and is classically considered to be composed of island arc volcano-sedimentary sequences with related calc-alkaline plutons resulting from a subduction with a Benioff plane dipping to the north (Saquaque et al., 1989; Hefferan et al., 2000). However, lower Neoproterozoic continental sedimentary series, as the Kelâat M'Gouna group (Fekkak et al., 1999), also occur in the Saghro region and $\mathrm{U}-\mathrm{Pb}$ on zircon age determinations on plutons show they are late (580-567 Ma; Errami, 1993; Mrini, 1993).

\subsection{The lower Neoproterozoic sedimentary series: the WAC passive margin}

These mildly deformed turbiditic sediments are several thousands meters thick (up to $>4000 \mathrm{~m}$ ), and contain zircons derived from peraluminous granites indicating a mature continental source (Fekkak et al., 1999). Basaltic dykes with continental tholeiites composition crosscut these sediments, the whole being compatible with an incipient rift (Mokhtari et al., 1995) within a continental passive margin (Fekkak et al., 1999) subjected to a rapid subsidence (Lecolle et al., 1991). Such aulacogen-type sedimentation on a cratonic edge (Fekkak et al., 1999) older than $788 \pm 9$ Ma (Clauer, 1976), could be contemporary to that of the Gourma aulacogen on the eastearn border of the WAC in Mali (1000-800 Ma; Moussine-Pouchkine and Bertrand-Sarfati,
1978; Fig. 3). A similar environment with clastic sediments and continental tholeiites marking a rifting event on the WAC passive margin in early Neoproterozoic is also described in Benin (Affaton et al., 1997). This rifting event may correspond to the initiation of the continental fragmentation that isolated the WAC till the end of the Pan-African orogeny.

These passive cratonic margin sediments can be correlated to the turbiditic sediments present in the Kerdous (Nachit et al., 1996) and Zenaga inliers, SW of the AAMF. There, the sedimentary pile is thinner (from 0 to $1000 \mathrm{~m}$, compared to $>4000 \mathrm{~m}$ in the Saghro aulacogen) but tholeiitic dykes are also present (Leblanc and MoussinePouchkine 1994; Ikenne et al., 1997; Hafid et al., 1999; Ennih et al., 2000).

This leads us to conclude that these sedimentary series, located to the NE and to the SW of the AAMF, both belong to the northern margin of the WAC itself and not as postulated earlier to a hypothetical northern continent (Leblanc and Lancelot, 1980; Saquaque et al., 1989; Fekkak et al., 1999).

\subsection{The Pan-African island arc series: relics of thrusting upon the West African craton passive margin}

The greenschist facies deformation within the Saghro volcano-sedimentary assemblage is characterized by a NE-SW schistosity, a stretching mineral lineation oriented to the $\mathrm{S}, \mathrm{NE}-\mathrm{SW}$ plunging fold axes overturned to the $S$, thrusts dipping to the SE and dextral E-W strike-slip shear zones (Ighid et al., 1989). At least a part of this sequence appears to belong to the lower Neoproterozoic sedimentary sequences described above (Fekkak et al., 1999). More work is needed to determine the amount of island arc material actually present in the Saghro. The presence of the Bou Azzer ophiolite even if it has been strongly affected by late transcurrent movements along the AAMF (thus blurring the original structures), attests to the presence of thrust oceanic material in Saghro. We can then interpret the structures described above as resulting from a 
thrusting event into the autochthonous turbiditic series from the aulacogen with possible island arc relics (linked to the Bou Azzer ophiolite), if their existence is demonstrated. These structures force a north to south movement.

The Saghro with only some thrust oceanic island arc relics therefore belongs to the WAC margin. The allochthonous Bou Azzer ophiolitic garland does not mark the suture that has to be located more to the north. In the Mauritanides, northwest and southwest of the Reguibat shield, as well as to the west of the Tuareg shield onto the Gourma aulacogen (Caby, 1978), PanAfrican upper crustal material has also been thrust upon the WAC (Fig. 3).
$\mathrm{U}-\mathrm{Pb}$ dating indicates that the high-K calcalkaline plutons intruded into the Saghro greenschist facies volcano-sedimentary sequences are late (580-567 Ma; Errami, 1993; Mrini, 1993). These granitoids are not linked to the island arc assemblage and subduction event ( $>685 \mathrm{Ma}$ ). Several factors suggest a post-collisional setting (Liégeois et al., 1998) within the sedimentary margin of the WAC for the Saghro granitoids, these are: an absence of Pan-African events between the thrust-related deformation and the granitoids; a weak metamorphism affecting their country-rocks; intrusion at a high level in the crust, their high-K calc-alkaline composition and subsequent alkaline magmatism.

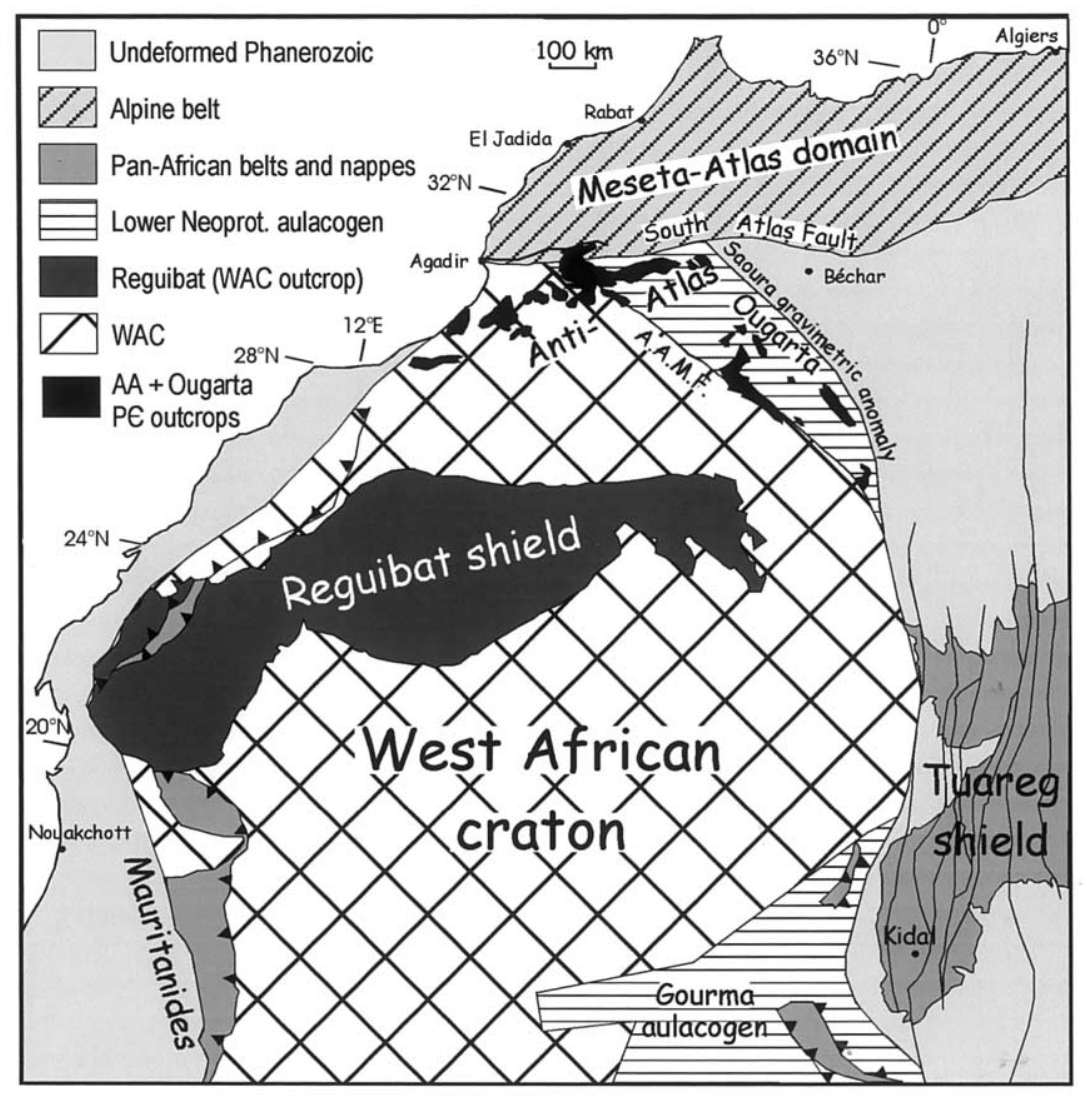

Fig. 3. WAC sketch map placing the Anti-Atlas into its regional context and showing the proposed northern and northeastern boundary of the WAC; it is suggested that the latter follows the Saoura gravimetric anomaly north of the Ougarta region and the SAF, rather than the AAMF (Anti-Atlas Major Fault), which probably corresponds only to a boundary fault of an aulacogen formed on the WAC passive margin during early Neoproterozoic times. Geological limits from Fabre (1971); gravimetric data from Bayer and Lesquer (1978). AA $+\mathrm{O}=$ Anti-Atlas + Ougarta. 


\section{Geodynamical significance of the Anti-Atlas Precambrian basement-correlation with the Pan-African events in the Tuareg shield and in the Avalonia-Cadomia terranes}

The model herein proposed takes into account the following points: (1) the whole Anti-Atlas area corresponds to the northern margin of the Eburnian WAC; (2) the latter continental passive margin formed at the beginning of the Neoproterozoic during a continental break-up when turbiditic series were deposited and dykes of continental tholeiitic basalts emplaced (Fekkak et al., 1999); (3) the WAC constitutes the source of these sedimentary series, their thickness increasing from the SW $(<1000 \mathrm{~m})$ to the NE $(>4000 \mathrm{~m})$; (4) during Pan-African times the subduction zones have to dip away from the WAC (Hefferan et al., 2000) that acted as a passive margin; (5) during an accretion phase, a Pan-African island arc was thrust onto the WAC together with an ophiolitic assemblage about $685 \mathrm{Ma}$ ago (Leblanc and Lancelot, 1980); (6) the flexure induced by the overload generated by the thrusting induced a proximal sedimentation of an early molasse, that of Tidiline (Hefferan et al., 1992) and of Kerdous (Hassenforder, 1987); (7) after a 100 m.y. quiescence period on both sides of the AAMF, high-K calc-alkaline and alkaline plutons associated with rhyolites and rift sediments were later emplaced (Aït Malek et al., 1998; Errami, 2001) around 585-560 Ma ago.

This indicates that the Neoproterozoic evolution of the Anti-Atlas is marked by a relatively weak imprint of the Pan-African orogeny in contrast with what occurred more to the east in the Tuareg shield (Black et al., 1994). Within the Tuareg shield, the Pan-African orogeny involves an early collision phase of several terranes with the East Saharan craton to the east from approximately $730 \mathrm{Ma}$ and a late collision with the WAC to the west from approximately $620 \mathrm{Ma}$, with protracted post-collisional events in both cases (Liégeois et al., 1994, 1998). Collisions are marked by high-pressure metamorphism and major thrusting towards rigid blocks while the post-collisional period is characterized by large horizontal movements of terranes and abundant high-K calc- alkaline batholiths (Liégeois et al., 1998). This is a major episode of the Gondwana formation.

During the collision period, in the Air region SE of the Tuareg shield, Aouzegueur (comprising an ophiolite; Boullier et al., 1991) and Barghot terranes were thrust onto the East Saharan craton at approximately $700 \mathrm{Ma}$ ago (Liégeois et al., 1994, 1998). This induced a cratonic flexure and the sedimentation of the Proche-Ténéré early molasse (Black, 1967; Liégeois et al., 2000). In these thrust terranes, orogenic events apparently ceased with the end of the thrusting around $665 \mathrm{Ma}$ ago (Black et al., 1991). In contrast, on the western side of the Raghane shear zone marking the western craton boundary, major orogenic events (amphibolite metamorphism, high-K calc-alkaline batholiths) occurred from 650 to $580 \mathrm{Ma}$, building most of the Tuareg shield. It is only at the very end of the orogeny (c. $530 \mathrm{Ma}$ ) that alkaline rhyolitic and quartz dykes affected both sides of the cratonic margin (Liégeois et al., 1994). On the WAC, early eclogite-bearing nappes are also preserved (Caby, 1978). This indicates that nappes thrust onto cratons (c. $700 \mathrm{Ma}$ on the ESC, c. 630 $\mathrm{Ma}$ on the WAC) were not affected by later orogenic events except, in some areas, by late high-level magmatism.

In the Tuareg shield, 23 terranes have been deciphered so far. Their general movements during the post-collisional periods were globally to the north. Their stacking was contemporary with the oblique arrival from SE of the WAC (Liégeois et al., 1987). Post-collisional deformation occurred mainly between 620 and 580 Ma (Liégeois et al., 1987, 1994). Such ages have also been recorded in Togo and Ghana with most $\mathrm{Ar}-\mathrm{Ar}$ ages found around 587-575 Ma with some up to $630 \mathrm{Ma}$ (Attoh et al., 1997). Shear zones delimiting the Tuareg terranes, progressively squeezed between the East Saharan and West African Cratons, became successively inactive between $592 \pm$ 6 Ma (Hadj Kaddour et al., 1998) and $523 \pm 1$ Ma (Paquette et al., 1998). Movements along the Raghane shear zone (western boundary of the East Saharan craton) ceased at approximately 580 Ma (Bertrand et al., 1978; Liégeois et al., 1994) and the huge alkaline-peralkaline magmatic province, associated with late movements along 
faults in the Iforas, SW Tuareg shield, occurred in the 560-540 Ma age range (Boullier et al., 1986; Liégeois et al., 1987, 1996).

At the end of Neoproterozoic, subsequently to a 760-660 Ma arc activity, Avalonia and Cadomia terranes accreted the Gondwanan margin at approximately 650-630 Ma, being the WAC for Cadomia (Strachan et al., 1996). During the 630$570 \mathrm{Ma}$ period, accreted Cadomia still faced an open ocean ('outboard terrane') and was affected by an abundant magmatism recycling the juvenile crust (Murphy et al., 2000). This magmatism described as arc magmatism could correspond to post-collisional magmatism as defined by Liégeois et al. (1998) and the orogenic system as a 'hit and run' orogeny (Maxson and Tikoff, 1996). Sinistral transform motion ending with intracontinental wrench-related bimodal volcanic and sedimentary rocks (570-550 Ma) are also depicted (Nance and Murphy, 1994; Murphy et al., 2000). This corresponds to the calc-alkaline-alkaline transition described at the end of the Pan-African orogeny in the Tuareg shield (Liégeois et al., 1987, 1998) and elsewhere (Bonin, 1990). In Cadomia, transpressive events locally occurred late with culmination of anatexis at approximately $540 \mathrm{Ma}$ (Brown and D'Lemos, 1991), in agreement with the 'outboard' situation of Cadomia (Murphy et al., 2000) and with the stress induced by the WAC and recorded in the Tuareg shield till approximately $523 \mathrm{Ma}$ (Paquette et al., 1998).

We therefore suggest the following model:

- Anti-Atlas corresponds to the northern boundary of the Eburnian WAC, including an early Neoproterozoic aulacogen probably marking, as the Gourma aulacogen, a continental break-up (Fig. 4A).

- At approximately $685 \mathrm{Ma}$, the northern border of the WAC collided with an oceanic convergent margin now preserved as juvenile thrust sheets in Saghro and Bou Azzer (ophiolite remnants; Fig. 4B).

- No apparent tectonic, metamorphic, magmatic events occurred in the Anti-Atlas during most of the Pan-African orogeny (from 685 to 585 Ma; Fig. 4C) due to the thick cratonic lithospheric mantle (Black and Liégeois, 1993). Avalonia-Cadomia terranes collided with the craton at 650-630 $\mathrm{Ma}$ and moved afterwards along a sinistral shear zone corresponding to the craton boundary currently marked by the SAF. The postulated subduction zone to the north (Nance and Murphy, 1994) can drive this sinistral movement as for the Assodé terrane in Aïr (Liégeois et al., 1994) but has no effect in Anti-Atlas. Palaeoproterozoic basement known in Cadomia (Calvez and Vidal, 1978) is very limited in volume and played a very limited role in the origin of Cadomian granites (Vidal et al., 1981). It could derived from the WAC (Nance and Murphy, 1996) maybe as a tectonic sliver introduced in Cadomia at that time.

- High-level magmatism intruded in Anti-Atlas in the 585-560 Ma age range as a result of the stress induced by the major phase of the terrane stacking in the Tuareg shield to the east, already accreted or still accreting onto the East Saharan craton (Fig. 4D, E). Anti-Atlas is indeed characterized by a relatively abundant late magmatism in the 585-560 Ma age range, high-level high-K calc-alkaline batholiths closely followed by alkaline plutons, to the south (Aït Malek et al., 1998) and to the north (Errami, 2001) of the AAMF with volcanic counterparts (respectively named the 'Precambrian III' and 'Adoudounian' volcanic series in the Moroccan literature).

- The post-orogenic sediments deposited onto the eroded belt in the Anti-Atlas are the socalled Adoudounian series. They occurred at the end of the Precambrian (called 'Infracambrien' in Morocco) since typical Cambrian fossils (trilobite, Archaeocyathides) appear quite high in the succession, with the lower series, $2000 \mathrm{~m}$ in thickness, containing only stromatolites (Choubert and Hupe, 1954). This provides an age for the beginning of the deposition of the Adoudounian series, i.e. before $544 \mathrm{Ma}$ (base of Cambrian; Bowring et al., 1993). The presence of alkaline volcanic rocks at the base of the Adoudounian series agrees with the age of approximately $560 \mathrm{Ma}$ measured on the late coeval Pan-African alkaline plutons (Aït Malek et al., 1998). Geodynamically, the Adoudounian series is equivalent to the post-orogenic Tassilis sandstones of the Tuareg shield, al- 
Plan view

A: Early Neoproterozoic

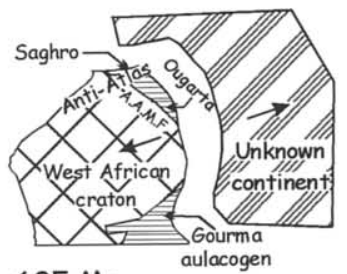

B: c. $685 \mathrm{Ma}$

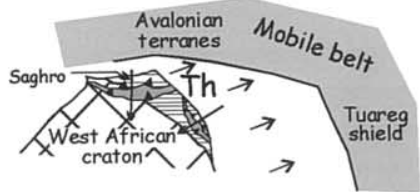

C: $650-580 \mathrm{Ma}$

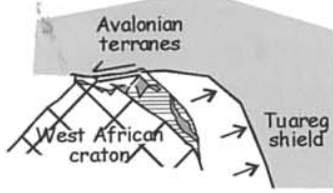

D: $580-560 \mathrm{Ma}$

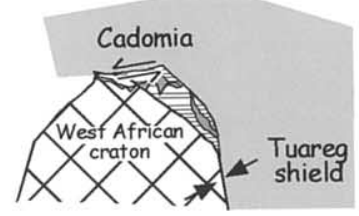

E: c. 570 Ma reconstruction

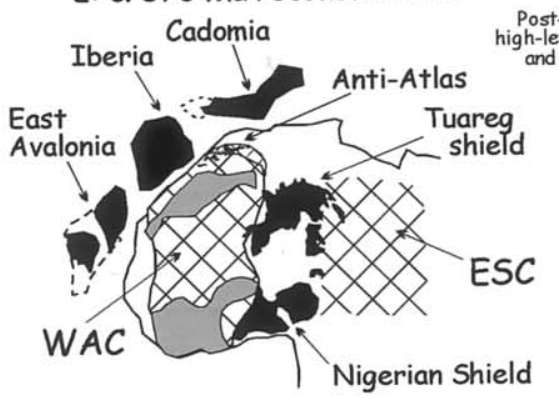

Cross-section

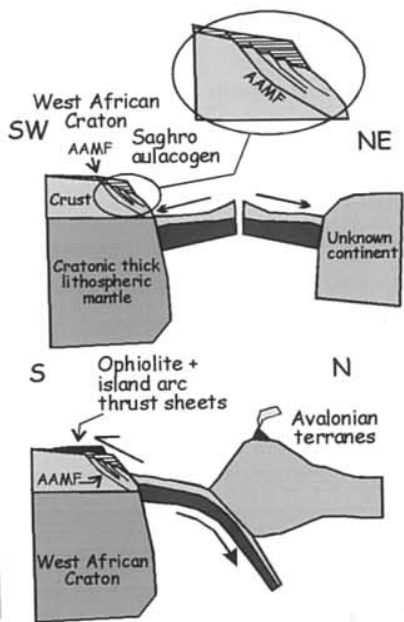

N

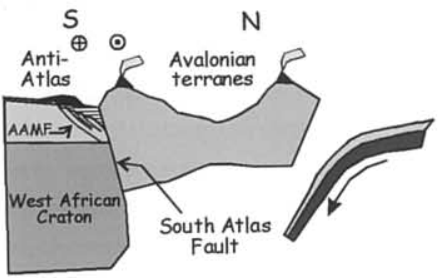

N

$S$

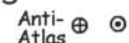

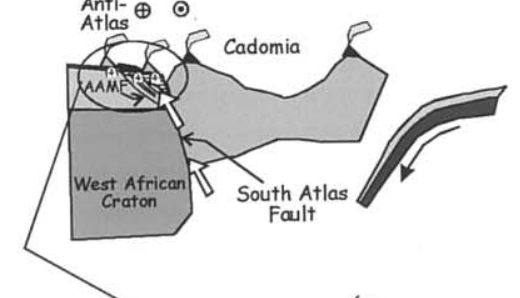

(including thrt sheets

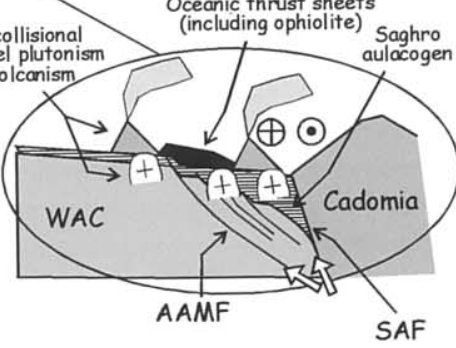

Fig. 4. (Continued) 
though they differ by about 50 m.y.; Tassilis sandstones unconformably lie on the eroded belt, including late molasses with alkaline rhyolites. lites. Their deposition began at the Cambrian-Ordovician boundary (Beuf et al., 1971) not long after the latest dated Pan-African alkaline granite $(523 \pm 1 \mathrm{Ma}$; Paquette et al., 1998). Stable platform sedimentation occurred in Anti-Atlas while the WAC was still in convergence with the Tuareg shield and with the Avalonian terranes. This demonstrates once more the very rigid behaviour of Anti-Atlas during the Pan-African orogeny.

Our model implies that intense Pan-African events occurred to the north of Anti-Atlas within the mobile belt itself. In addition to Avalonia and Cadomia, expressions of these events may be found in relics located within the Variscan and Alpine belts of the Meseta-Atlas domain to the north of the South Atlas fault such as in the Ouzellagh of the Massif Ancien from the High Atlas (Jouhari et al., 2000). The Pan-African belt originally located to the north of Anti-Atlas is now dismembered.

This model may be tested by more extensive high precision $\mathrm{U}-\mathrm{Pb}$ dating of plutons in the Anti-Atlas region.

\section{Significance of the South-Atlas Fault and Anti-Atlas Major Fault}

During the Pan-African, the AAMF is characterized by sinistral strike-slip movements (Ennih et al., 2001) and delineates the SW boundary of an early Neoproterozoic subsidence area ( $>4000 \mathrm{~m}$ of sediments compared to $<1000 \mathrm{~m}$ ). Pan-African movements along the AAMF occurred on a pre-existing fracture affecting the craton itself, probably a main border fault of the aulacogen (Fig. 4A-D) described by Fekkak et al. (1999). Pan-African post-collisional transpression along this fracture produced a greater uplift to the SW than to the NE, enhancing the greater subsidence that occurred earlier during the aulacogen formation. The PanAfrican nappes should then be better preserved to the NE of the AAMF (as in Saghro and Siroua) than to the SW. A similar situation is found in Mali where the early Pan-African nappes thrust upon the WAC are mainly preserved on the Gourma aulacogen (Caby, 1978). During the post-collisional period, the SAF and AAMF experienced a major transpression period which ended with the Tuareg terrane stacking and generated in Anti-Atlas high$\mathrm{K}$ calc-alkaline batholiths and lavas (Fig. 4C, D). This period was followed by a transtension event, with minor alkaline plutons and lavas. Following Pan-African orogeny, the AAMF played no major geological role during the Phanerozoic, suggesting that it is no longer a major lithospheric-scale active structure.

Our proposal is that the actual northern limit of the WAC is marked by the SAF; the Pan-African lithologies to the south constitute either allochthonous thrust sheets or late post-collisional magmatism. In this area the SAF therefore constitutes the major geosuture. Indeed, only regions located to the north of the SAF have been strongly affected by Phanerozoic orogenies. The SAF was active dextrally during the Variscan orogeny (Petit and Beauchamp, 1986) and sinistrally during the Alpine orogeny (Laville and Petit, 1984). The Phanerozoic sedimentary sequences are strongly

Fig. 4. Simplified model of the Anti-Atlas behaviour during the Neoproterozoic. (A) Saghro aulacogen (Fekkak et al., 1999) formation supposed to be contemporary to that of Gourma aulacogen (1000-800 Ma; Moussine-Pouchkine and Bertrand-Sarfati, 1978), marking a continental break-up. AAMF is the main aulacogen border fault, with differences in passive margin sediment thickness on each side. (B) Material from a Pan-African oceanic convergent (including ophiolite) has been thrust upon the craton mainly from $\mathrm{N}$ to $\mathrm{S}$ at approximately $685 \mathrm{Ma}$ (Leblanc, 1981). Avalonian terranes are not far in the open sea, accretion beginning at approximately $650 \mathrm{Ma}$ (Strachan et al., 1996). (C) Quiescence period (680-585 Ma) with no event in the Anti-Atlas region due to relatively free movement of the rigid WAC; Avalonian terranes, by contrast, are subjected to various metamorphic and magmatic events (Murphy et al., 2000). (D) Injection of Pan-African high-K calc-alkaline and alkaline granitoids and lavas (pathways indicated in the cross-section by white arrows) at the very end of the orogeny (585-560 Ma) on both sides of AAMF (Errami, 1993; Mrini, 1993; Ait Malek et al., 1998), during the main squeezing of the terranes in the Tuareg shield that induced additional stress on the northern boundary of the WAC. (E) Position of the Anti-Atlas within the reconstituted Pan-African belt at 630-570 Ma (after Nance and Murphy, 1996). 
folded to the north of the SAF and relatively undeformed (flat-lying) to the south. During the Cainozoic, phonolitic volcanism (Tinghir and Siroua areas; Hindermeyer, 1977) and the historical seismicity of Agadir region (Fig. 3) occurred along the SAF. We suggest that the reactivation of the SAF probably induced a slight uplift of the northern margin of the craton, bringing to the surface parts of the Precambrian basement, the current Anti-Atlas inliers.

\section{The Algerian Ougarta: a similar situation?}

The AAMF continues SE to Algeria, extending to the SW of the Ougarta area (Fig. 3). In Ougarta, as in Anti-Atlas, Neoproterozoic sediment series are $4-5 \mathrm{~km}$ thick. These series were deposited in a shallow marine environment (Caby, 1996) and later subjected to mild greenschist facies metamorphism. Upper parts are greywackes rich in volcanic material while the base is enriched in terrigeneous debris with the presence of magmatic or metamorphic microcline, muscovite and fragments of metamorphic rocks (Caby, 1996). The upper mainly volcanic part corresponds to a Pan-African island arc assemblage (Dostal et al., submitted). The origin of the lower part is probably similar to the Anti-Atlas passive marine aulacogen: the detrital material suggests a WAC source rather than an island arc. This will be tested through $\mathrm{T}_{\mathrm{DM}} \mathrm{Nd}$ model ages (Liégeois and Caby, in preparation).

In consequence, we propose that the northeastern limit of the WAC should pass to the $\mathrm{N}$ and to the E of the Ougarta region (Fig. 3). Geophysical data support this view: the AAMF is not marked by a Bouguer gravity anomaly in contrast to the Saoura valley marking the northern limit of the Ougarta area (Bayer and Lesquer, 1978; Fig. 3). An isobath map (Fig. 5) showing the Precambrian basement depth (Takherist, 1991) indicates that the Ougarta constitutes the steep margin of the craton, with some uplifted basement blocks. This situation is similar to the European platform and Alpine orogeny where the external crystalline massifs (Mont Blanc, Aar...) constitute uplifted blocks of the former European passive margin

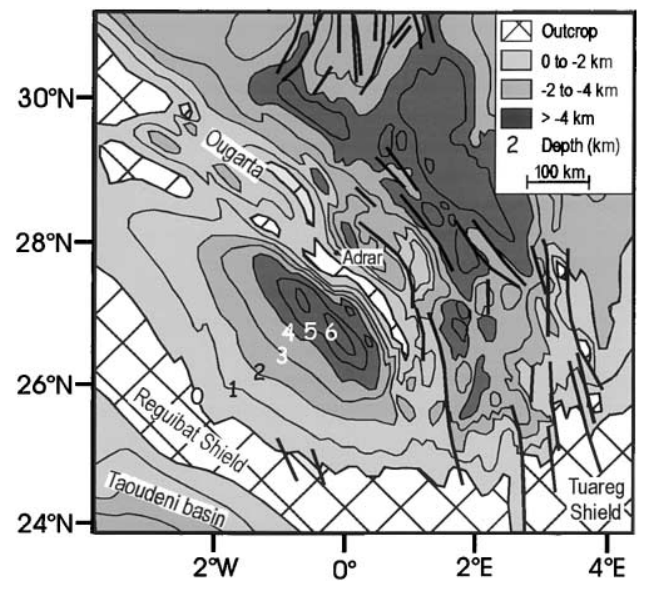

Fig. 5. Isobath map of Palaeozoic base, corresponding to the Precambrian basement of the Ougarta region. Depth between lines: $1 \mathrm{~km}$. From Takherist (1991). Depth of the Precambrian basement shows the descending margin of the craton and the existence of uplifted basement blocks. The main faults delineate the proposed new boundary of the WAC.

(see, e.g. the recent synthesis of Mosar, 1999). Fifty $\mathrm{km}$ to the west of Adrar (Fig. 5), a small outcrop of the WAC basement is present (Djebel Heirane; Caby, 1996), indicating its likely presence below the other Ougarta inliers. The major faults north of Ougarta are oriented NW-SE. In contrast, to the east or more to the north of Ougarta (Takherist, 1991; Fig. 5), the general $\mathrm{N}-\mathrm{S}$ orientation of the Trans-Saharan belt prevails, as in the Tuareg shield (Black et al., 1994).

\section{Conclusions}

The northern limit of the WAC is marked by the SAF. We believe that this is the reason why Variscan and Alpine orogeny effects are very weak to the south of this major lithospheric structure. We suggest that the classical craton boundary, the AAMF, corresponds to the southwestern border fault of an aulacogen (Fekkak et al., 1999) generated during a continent break-up probably 1000-800 Ma ago and located inside the WAC. This interpretation is similar to one proposed for the Gourma aulacogen on the eastern side of the WAC (Moussine-Pouchkine and Bertrand-Sarfati, 1978). The greater subsidence to the NE of this fault allows not only several thou- 
sand meters of lower Neoproterozoic sediment deposition but also the preservation from erosion of some island arc assemblage relics, including ophiolite, thrust upon this former passive margin at approximately $685 \mathrm{Ma}$ (Leblanc, 1981).

Pan-African material thrust upon the WAC was protected by the cratonic thick lithosphere (Black and Liégeois, 1993) during the subsequent Pan-African orogenic events. The major part of the belt has to be searched as relics in the Variscan-Alpine Atlas-Meseta area (Jouhari et al., 2000) as well as in Cadomia, close to Anti-Atlas at the end of Neoproterozoic (Nance and Murphy, 1996; Murphy et al., 2000). The Anti-Atlas area was only affected by late high-K calc-alkaline and alkaline magmatism at the end of the orogeny at approximately 585-560 Ma (Ait Malek et al., 1998; Errami, 1993, 2001) on both sides of the AAMF. This implies a 100 m.y. quiescence in the Anti-Atlas area between approximately 685 and $585 \mathrm{Ma}$.

We conclude that the Anti-Atlas crust is Eburnian in age (with typical peraluminous granitoids) with a lower Neoproterozoic sedimentary cover, thin to the south but that thickens to the north of the AAMF, a thrust Pan-African oceanic island arc assemblage and late post-collisional PanAfrican (585-560 Ma) high-K calc-alkaline and alkaline granites with associated volcanic rocks. This magmatism is contemporary to the main phase of stacking of the Tuareg shield terranes that induced additional stress on the northern boundary of the WAC.

That the South Atlas Fault is the northern limit of the WAC implies that this boundary continues to the north, and not to the south, of the Ougarta area in Algeria. This is corroborated by geophysical data. This new interpretation adds nearly 100 $000 \mathrm{~km}^{2}$ to the WAC and has major implications for geodynamical modelling.

\section{Acknowledgements}

We thank E. Errami for providing us with her geochemical data and R. Greiling for discussions and careful reading of the manuscript. This paper greatly benefited from the thorough and construc- tive reviews by K.P. Hefferan and K. Attoh. Thanks to W.E.E. Stone for helping us with the English of the last version.

\section{References}

Affaton, P., Aguirre, L., Ménot, R.P., 1997. Thermal and geodynamic setting of the Buem volcanic rocks near Tiélé, Northwest Bénin, West Africa. Precambrian Res. 82, 191209.

Attoh, K., Dallmeyer, R.D., Affaton, P., 1997. Chronology of nappe assembly in the Pan-African Dahomeyide orogen, West Africa: evidence from 40Ar/39Ar mineral ages. Precambrian Res. 82, 153-171.

Aït Malek, H., Gasquet, D., Bertrand, J.M., Leterrier, J., 1998. Géochronologie $\mathrm{U}-\mathrm{Pb}$ sur zircon de granitoïdes éburnéens et panafricains dans les boutonnières d'Igherm, du Kerdous et du Bas Drâa (Anti-Atlas occidental, Maroc). C. R. Acad. Sci. Paris 327, 819-826.

Bayer, R., Lesquer, A., 1978. Les anomalies gravimétriques de la bordure orientale du craton ouest-africain: géométrie d'une suture pan-africaine. Bull. Soc. Géol. Fr. 20, 863876.

Beuf, S., Biju Duval, B., De Charpal, O., Rognon, R. and Bennacef, A., 1971. Les grès du Paléozoïque inférieur au Sahara. Sédimentations et continuités; évolution structurale d'un craton. Publ. Inst. Fr. Pétrole, Coll. Sci et Tech. du Pétrole 18, Technip ed. Paris, 464 pp.

Bertrand, J.M.L., Caby, R., Lancelot, J.R., MoussinePouchkine, A., Saadallah, A., 1978. The late Pan-African intracontinental fold belt of the eastern Hoggar (central Sahara, Algeria): geology, structural development, $\mathrm{U}-\mathrm{Pb}$ geochronology, tectonic implications for the Hoggar shield. Precambrian Res. 7, 349-376.

Black, R., 1967. Carte géologique de reconnaissance du massif de l'Aïr à l'échelle du 1:500000. Ministère des Mines et de l'Energie, République du Niger, Niamey.

Black, R., Liégeois, J.P., 1993. Cratons, mobile belts, alkaline rocks and the continental lithospheric mantle: the PanAfrican testimony. J. Geol. Soc. Lond. 150, 89-98.

Black, R., Liégeois, J.P., Navez, J., Vialette, Y., 1991. Terrains exotiques dans les zones internes de la chaîne pan-africaine trans-saharienne: les clefs fournies par l'Aïr sud-oriental (République du Niger). C. R. Acad. Sci. Paris 312, 889895.

Black, R., Latouche, L., Liégeois, J.P., Caby, R., Bertrand, J.M., 1994. Pan-African displaced terranes in the Tuareg shield (central Sahara). Geology 22, 641-644.

Bonin, B., 1990. From orogenic to anorogenic settings: evolution of granitoid suites after a major orogenesis. Geol. J. 25, 261-270 (W.S. Pitcher Special Issue).

Boullier, A.M., Liégeois, J.P., Black, R., Fabre, J., Sauvage, M., Bertrand, J.M., 1986. Late Pan-African tectonics marking the transition from subduction-related calc-alkaline magmatism to within-plate alkaline granitoids (Adrar des Iforas, Mali). Tectonophysics 132, 233-246. 
Boullier, A.M., Rocci, G., Cosson, Y., 1991. La chaîne panafricaine d'Aouzegueur en Aïr (Niger): un trait majeur du bouclier touareg. C. R. Acad. Sci. Paris 313, 63-68.

Bowring, S.A., Grotzinger, J.P., Isachsen, C.E., Knoll, A.H., Pelechaty, S.M., Kolosov, P., 1993. Calibrating rates of Early Cambrian evolution. Science 261, 1293-1298.

Brown, M., D'Lemos, R.S., 1991. The Cadomian granites of Mancellia, northeast Armorican Massif of France: relationship to the St Malo migmatite belt, petrogenesis and tectonic setting. Precambrian Res. 51, 393-427.

Caby, R., 1978. Paléogéodynamique d'une marge passive et d'une marge active au Précambrien supérieur: leur collision dans la chaîne pan-africaine du Mali. Bull. Soc. Géol. Fr. 20, 857-862.

Caby, R., 1996. Rapport de la mission de terrain dans le Grand Sud-Ouest algérien (7-22 novembre 1996). Mémoire Service Géologique Algérie 8, 49-51.

Calvez, J.Y., Vidal, P., 1978. Two billion years old relicts in the Hercynian belt of Western Europe. Contrib. Miner. Petrol. 65, 395-399.

Charlot, R., 1978. Caractérisation des événements éburnéens et panafricains dans l'Anti-Atlas marocain. Apport de la méthode géochronologique $\mathrm{Rb}-\mathrm{Sr}$. Notes Mém. Serv. Géol. Maroc 313, 106pp.

Choubert, G., 1963. Histoire géologique du Précambrien de l'Anti-Atlas. Notes Mém. Serv. Géol. Maroc 162, 352pp.

Choubert, G., Hupe, P., 1954. Formation à Trilobites du Cambrien inférieur sur le pourtour de l'Anti-Atlas occidental. C. R. Acad. Sci. Paris 239, 1817-1819.

Clauer, N., 1976. Géochimie isotopique du strontium des milieux sédimentaires. Application à la géochronologie du craton ouest africain. Thèse Univ. Strasbourg, France, $227 \mathrm{pp}$.

Dostal, J., Caby, R. and Keppie, J. D.. Neoproterozoic arc magmatism in Southwestern Algeria (Sebkha el Melah inlier): a northerly extension of the Trans-Saharan orogen. J. Afr. Earth Sci., submitted for publication.

Ennih, N., Errami, E., Laduron, D., Greiling, R.O., Masi, U., 2000. Les dykes basiques protérozoïques de la boutonnière de Zenaga (Anti-Atlas central, Maroc): signification géotectonique. 18th Coll. Afr. Geol., Graz, Austria. J. Afr. Earth Sci. 30, 29-30 (abstract).

Ennih, N., Laduron, D., Greiling, R.O., Errami, E., de Wall, H., Boutaleb, M., 2001. Superposition de la tectonique éburnéenne et panafricaine dans les granitoïdes de la bordure nord du craton ouest africain (Boutonnière Zenaga: Anti-Atlas central, Maroc). J. Afr. Earth Sci., 32(4).

Errami, E., 1993. Granitoïdes d'Oussilkane et roches associées (Précambrien du Saghro oriental, Anti-Atlas, Maroc) Pétrographie, minéralogie et géochimie. Approche Structurale). Thèse Univ. Marrakech, 225pp.

Errami, E., 2001. Les granitoïdes panafricains post-collisionnels du Saghro oriental (Anti-Atlas, Maroc). Une étude pétrologique et structurologique par l'anisotropie de susceptibilité magnétique. Thèse Univ. El Jadida, 250pp.

Fabre, J., 1971. Introduction à la géologie du Sahara. S.N.E.D., Alger, 422pp.
Fekkak, A., Boualoul, M., Badra, L., Amenzou, M., Saquaque, A., El Imrani, I.E., 1999. Origine et contexte géotectonique des dépots détritiques du Groupe néoprotérozoïque inférieur de Kelâat Mgouna (Anti-Atlas oriental, Maroc). J. Afr. Earth Sci. 30, 295-311.

Hadj Kaddour, Z., Liégeois, J.P., Demaiffe, D., Caby, R., 1998. The alkaline-peralkaline granitic post-collisional Tin Zebane dyke swarm (Pan-African Tuareg shield, Algeria): prevalent mantle signature and late agpaitic differentiation. Lithos 45, 223-243.

Hafid, A., Sagon, P., Saquaque, A., El Boukhari, A., Saïdi, A., 1999. Pétrologie et contexte géodynamique du magmatisme basique néoprotérozoïque de la boutonnière d'IguerdaTaïfast (Anti-Atlas central, Maroc). Africa Geosci. Rev. 6, $121-133$.

Hassenforder, B., 1987. La tectonique pan-africaine et varisque de l'Anti-Atlas dans le massif de Kerdous (Maroc). Thèse, Univ. Strasbourg, 249pp.

Hefferan, K.P., Karson, J.A., Saquaque, A., 1992. Proterozoic collisionnal basins in a Pan-African suture zone, Anti-Atlas Mountains, Morocco. Precambrian Res. 54, 295-319.

Hefferan, K.P., Admou, H., Karson, J.A., Saquaque, A., 2000. Anti-Atlas (Morocco) role in Neoproterozoic Western Gondwana reconstruction. Precambrian Res. 103, 89-96.

Hindermeyer, J., 1977. Carte Géologique du Jbel SaghroDadès au 1/200.000. Notes Mém. Serv. Geol. Maroc, 161.

Ikenne, M., Mortaji, A., Gasquet, D., Stussi, J.P., 1997. Les filons basiques des boutonnières du Bas Drâa et de la Tagragra d'Akka: témoins des distensions néoprotérozoïques de l'Anti-Atlas occidental (Maroc). J. Afr. Earth Sci. 25, 209-223.

Ighid, L., Saquaque, A., Reuber, I., 1989. Plutons syncinématiques et la déformation panafricaine majeure dans le Saghro oriental (Boutonnière d'Imiter, Anti-Atlas, Maroc. C. R. Acad. Sci. Paris 309, 615-620.

Jouhari, A., El Archi, A., Aarab, M., El Attari, A., Ennih, N., Laduron, D., 2000. Geochemistry of Neoproterozoic-cambrian volcanism in the Western High Atlas and Western Méséta, Morocco. 18th coll. Afr. Geol. Graz, Austria. J. Afr. Earth Sci 30, 43 (abstract).

Laville, E., Petit, J.P., 1984. Role of synsedimentary strike-slip faults in the formation of Moroccan Triasic bassins. Geology $12,424-427$.

Leblanc, M., 1981. Ophiolites précambriennes et gîtes arséniés de cobalt (Bou-Azzer, Maroc). Notes Mém. Serv. Géol. Maroc 280, 306pp.

Leblanc, M., Lancelot, J.R., 1980. Interprétation géodynamique du domaine Pan-Africain (Précambrien terminal) de l'Anti-Atlas (Maroc) à partir de données géologiques et géochronologiques. Can. J. Earth Sci. 17, 142-155.

Leblanc, M., Moussine-Pouchkine, A., 1994. Sedimentary and volcanic evolution of a Neoproterozoic continental margin (Bleida, Anti-Atlas, Morocco). Precambrian Res. 70, 2544.

Lecolle, M., Derré, C., Rjimati, E., Nerci, K., Azza, A., Bennani, A., 1991. Les distensions de la tectonique biphasée du panafricain de l'Anti-Atlas oriental: dynamique de 
dépôts et de structuration des Précambriens II-2 et II-3 (Saghro, Maroc). C. R. Acad. Sci. Paris 313, 1563-1568.

Liégeois, J.P., Bertrand, J.M., Black, R., 1987. The subduction- and collision-related Pan-African composite batholith of the Adrar des Iforas (Mali): a review. In: Kinnaird, J., Bowden, P. (Eds.), African Geology Review. Wiley, London, pp. 185-211 and Geol. J. 22, 185-211.

Liégeois, J.P., Black, R., Navez, J., Latouche, L., 1994. Early and late Pan-African orogenies in the Aïr assembly of terranes (Tuareg shield, Niger). Precambrian Res. 67, 5988.

Liégeois, J.P., Diombana, D., Black, R., 1996. The Tessalit ring complex (Adrar des Iforas, Malian Tuareg shield): a Pan-African, post-collisional, syn-shear, alkaline granite intrusion. In: Demaiffe, D. (Ed.), Petrology and Geochemistry of Magmatic Suites of Rocks in the Continental and Oceanic Crust, A volume dedicated to J. Michot. ULBMRAC, Brussels, pp. 227-244.

Liégeois, J.P., Navez, J., Hertogen, J., Black, R., 1998. Contrasting origin of post-collisional high-K calc-alkaline and shoshonitic versus alkaline and peralkaline granitoids. Lithos 45, 1-28.

Liégeois, J.P., Latouche, L., Navez, J., Black, R., 2000. PanAfrican collision, collapse and escape tectonics in the Tuareg shield: relations with the East Saharan Ghost craton and the West African craton. 18th Colloquium of African Geology, Graz, Austria. J. Afr. Earth Sci 30, 53-54 (abstract).

Maxson, J., Tikoff, B., 1996. Hit-and-run collision model for the Laramide orogeny, western United States. Geology 24, 968-972.

Mokhtari, A., Gasquet, D., Rocci, G., 1995. Les tholéïtes de Tagmout (Jbel Saghro, Anti-Atlas, Maroc) témoins d'un rift au Protérozoïque suupérieur. C. R. Acad. Sci. Paris 320, 381-386.

Mosar, J., 1999. Present-day and future tectonic underplating in the western Swiss Alps: reconciliation of basement/ wrench-faulting and décollement folding of the Jura and Molasse basin in the Alpine foreland. Earth Planet. Sci. Lett. 173, 143-155.

Moussine-Pouchkine, A., Bertrand-Sarfati, J., 1978. Le Gourma: un aulacogène du Précambrien supérieur? Bull. Soc. Géol. Fr. 20, 851-856.

Mrini, Z., 1993. Chronologie $(\mathrm{Rb}-\mathrm{Sr}, \mathrm{U}-\mathrm{Pb})$ et traçage isotopique $(\mathrm{Sr}-\mathrm{Nd}-\mathrm{Pb})$ des sources de roches magmatiques éburnéennes, panafricaines et hercyniennes du Maroc. Thèse Univ. Marrakech, 276pp.

Murphy, J.B., Strachan, R.A., Nance, R.D., Parker, K.D., Fowler, M.B., 2000. Proto-Avalonia: a 1.2-1.0 Ga tectonothermal event and constraints for the evolution of Rodinia. Geology 28, 1071-1074.

Nachit, H., Barbey, P., Pons, J., Burg, J.P., 1996. L'Eburnéen existe-t-il dans l'Anti-Atlas occidental marocain? L'exemple du massif du Kerdous. C. R. Acad. Sci. Paris 322, 677-683.

Nance, R.D., Murphy, J.B., 1994. Contrasting basement isotopic signatures and the palinspatic restoration of peripheral orogens: example from the Neoproterozoic Avalonian-Cadomian belt. Geology 22, 617-620.

Nance, R.D., Murphy, J.B., 1996. Basement isotopic signatures and Neoproterozoic paleogeography of AvalonianCadomian and related terranes in the Circum North Atlantic. In: Nance, R.D., Thompson, M.D. (Eds.), Avalonian and Related Peri-Gondwanan Terranes of the Circum North Atlantic, Geol. Soc. Am. Boulder, Colorado Spec. Paper, 304, pp. 333-346.

Paquette, J.L., Caby, R., Bouchez, J.L., 1998. A Cambrian stage of late Pan-African tectono-magmatic event: evidence from $\mathrm{U}-\mathrm{Pb}$ dating of a syn-tectonic Taourirt pluton (Tiouéine massif, western Hoggar, Algeria). Lithos 45, 245-254.

Petit, J.P., Beauchamp, J., 1986. Synsedimentary faulting and paleocurrent and patterns in the Triassic sandstones of High Atlas (Morocco). Sedimentology 33, 817-829.

Saquaque, A., Admou, H., Karson, J.A., Hefferan, K.P., Reuber, I., 1989. Precambrian accretionary tectonics in the Bou-Azzer El Graara region, Anti-Atlas. Geology 17, 1107-1110.

Strachan, R.A., Nance, R.D., Dallmeyer, R.D., D'Lemos, R.S., Murphy, J.B., 1996. Late Precambrian tectonothermal evolution of the Malverns complex, UK. J. Geol. Soc. Lond. 153, 589-600.

Takherist, D., 1991. Structure crustale, subsidence mésozoïque et flux de chaleur dans les bassins nord-sahariens (Algérie): apport de la gravimétrie et des données de puits. Documents et travaux du CGG, Montpellier, no. 29, 235pp.

Vidal, P., Auvray, B., Charlot, R., Cogné, P., 1981. Precadomian relicts in the Armorican massif: their age and role in the evolution of the western and central European Cadomian-Hercynian belt. Precambrian Res. 14, 1-20. 